\title{
Decisions by new Ontario government worry science and health care communities
}

\author{
Cite as: CMAJ 2018 July 30;190:E917-8. doi: 10.1503/cmaj.109-5635
}

Posted on cmajnews.com on July 10, 2018.

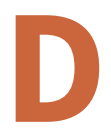
oug Ford has been premier of Ontario for less than two weeks, but his Progressive Conservative party has already made changes that have raised alarm in health care and scientific circles.

On June 30 , the day after the party took power, the province's new minister of health and long-term care, Christine Elliott, announced that Ontario children and youth will no longer be eligible for free prescription drugs if they already have private coverage. Under $\mathrm{OHIP+}$, the youth pharmacare program created by the previous Liberal government, every resident aged 24 and under received free coverage on more than 4400 medications. According to Elliott, the move is a "costeffective" measure, and the program will now focus on those "who do not have existing prescription drug benefits" while "saving the taxpayers money."

But according to Steve Morgan, a pharmacare expert and professor at the University of British Columbia School of Population and Public Health, the changes to $\mathrm{OHIP+}$ will not save the province money, won't provide better coverage of medications for Ontarians, and will hit the middle class the hardest. Privatizing drug coverage for children and youth will cost business owners and workers hundreds of millions of dollars, reduce cost control for necessary medicines, lead to an increase in administration expenses, and create barriers to coverage and access, Morgan noted in a recent opinion piece. "Being new, OHIP+ was an obvious choice for the first public drug benefit to be privatized by the Ford government in this inefficient and inequitable way. But it may not be the last," wrote Morgan. "Seniors, in particular, should take note: their benefits might be next."
The Ontario Health Coalition also raised alarm about the change to OHIP+, calling it a disturbing first act for a new provincial government. The coalition stated that it is unclear how private insurers and the public system will work together and which costs will remain eligible for reimbursement. "For people with kids with cancer or with serious illnesses, drugs can run up to $\$ 5000$ or even more," noted Natalie Mehra, the coalition's executive director. "That means copayments of hundreds of dollars a month."

The new Ontario government was also quick to fire the province's first-ever chief science officer. Biomedical engineer Molly Schoichet had been appointed to the role by former premier Kathleen Wynne to advise on research conducted in the province and to promote it across Canada and internationally. The Progressive Conservatives announced they are looking for a "suitable and qualified replacement," but provided no details on the firing of Schoichet, who was in the position for less than seven months.

Removing Schoichet from her position was a mistake, according to Peter Tabuns, a New Democrat member of the Legislative Assembly of Ontario. "You actually need science to protect human health and build the economy," he noted on Twitter. "Firing the person that helps guide both is a big step backwards."

The firing of Ontario's chief science officer is "very disappointing news, and

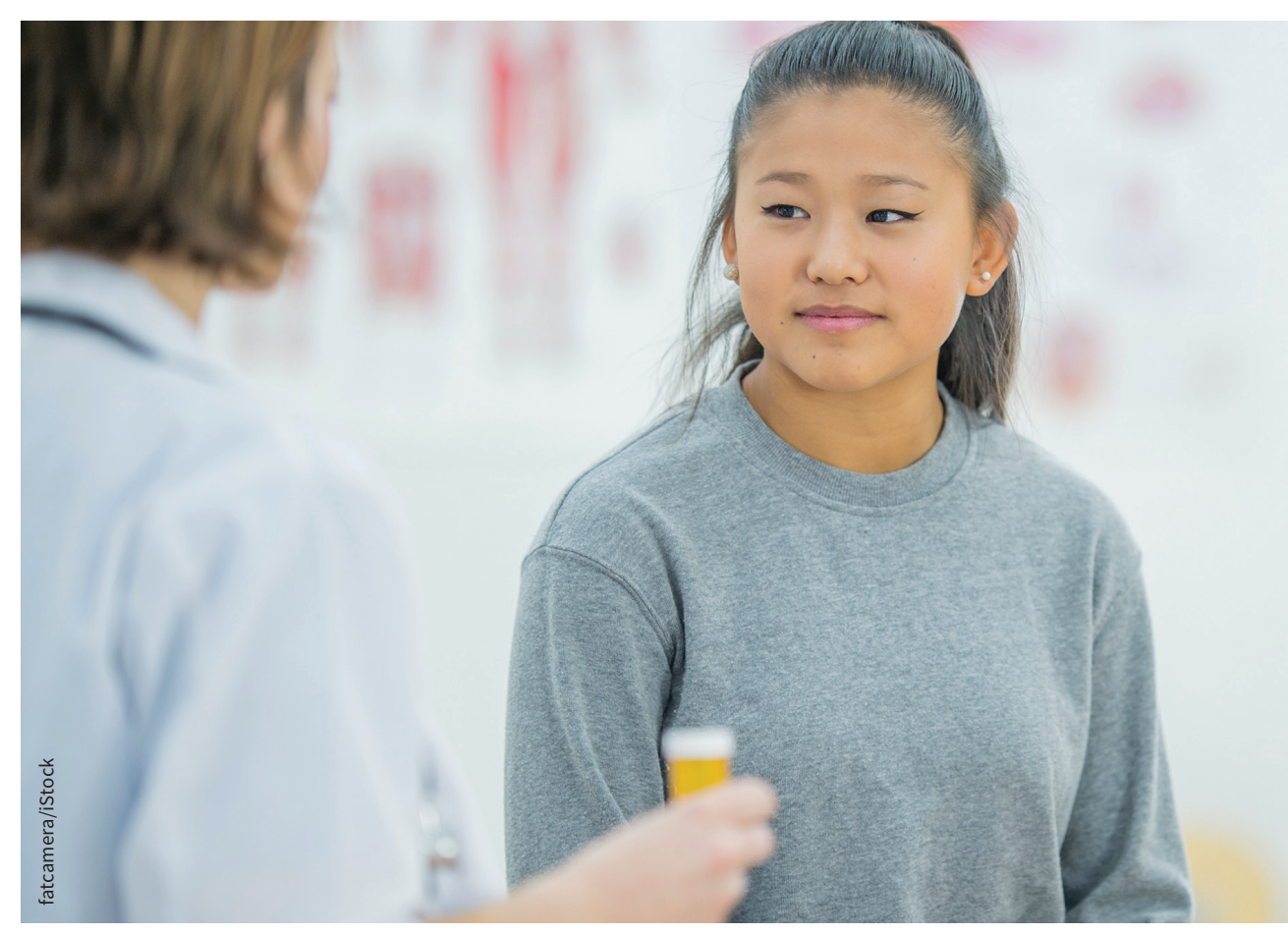

Changes to the province's youth pharmacare program were among the new Ontario government's first major decisions. 
signals a worrying pattern," according to a July 4 statement by Katie Gibbs, executive director of Evidence for Democracy, a nonprofit organization that advocates for evidence-based decision-making in government. "Premier Ford has been in power for less than a week and has already dismissed Ontario's chief scientist, cut government subscriptions to scientific publications, and reduced all travel for public servants, including to scientific conferences."

Premier Ford did, however, appoint someone to a new health care position. Dr. Ruben Devlin, an orthopedic surgeon and former president of the Ontario Progressive Conservatives, was named chair of a new body called the Premier's Council on Improving Healthcare and Ending Hallway Medicine. Devlin, who also served as president and CEO of Humber River Hospital for 17 years, will receive an annual salary of $\$ 348,000$ and be tasked with advising the premier on how to improve Ontario's health care system.

Another health-related government decision is raising concerns among antitobacco advocates. On July 1 , new regulations were set to come into effect that would have placed stiff restrictions on where people can use vaping products and how those products could be marketed. However, the Progressive Conservatives halted the new rules to provide the government with time to "work with the public, experts, and businesses to re-examine the evidence related to vaping as a smokingcessation tool to ensure that any changes are in the best interests of everyone and protect Ontarians' health and safety."

The move was lauded by vaping advocates but drew criticism from the Ontario Campaign for Action on Tobacco. "Kids could vape on school property as of Sept. 4. Without the pause, they wouldn't be able to," noted Michael Perley, the organization's director. "We have two months to go before school starts and it's summertime. Can a review be completed in time?"

On a more positive note, at least for Ontario's physicians, the new government has reached out to the Ontario Medical Association (OMA) to restart negotiations on a physician services agreement. The province's physicians have been without a contract for more than four years. OMA President Dr. Nadia Alam stated that the association has seen "strong signals from the new government that suggests that they want a different kind of relationship" with doctors than the previous administration, but physicians remain "cautiously hopeful" because "we've been burned by the government in the past."

Concerns raised by the OMA about a proposed amendment to the province's Immunization of School Pupils Act resulted in the government putting a hold on a rule that would have required doctors and nurses to report all immunizations administered to children. According to Alam, the proposed vaccination reporting rule "was unfeasible, just practically speaking." Although Dr. Eileen de Villa, Toronto's medical officer of health, said she supports the notion of direct reporting of immunization from health providers because it would result in more accurate records, she acknowledged that the province first needs an electronic system that would allow providers to transfer that information into public health databases seamlessly.

Roger Collier, CMAJ 